\title{
The effect of disturbance on an ant-plant mutualism
}

\author{
Jonah Piovia-Scott
}

Received: 2 April 2010 / Accepted: 9 November 2010 / Published online: 27 November 2010

(C) The Author(s) 2010. This article is published with open access at Springerlink.com

\begin{abstract}
Protective ant-plant mutualisms-where plants provide food or shelter to ants and ants protect the plants from herbivores-are a common feature in many ecological communities, but few studies have examined the effect of disturbance on these interactions. Disturbance may affect the relationship between plants and their associated ant mutualists by increasing the plants' susceptibility to herbivores, changing the amount of reward provided for the ants, and altering the abundance of ants and other predators. Pruning was used to simulate the damage to buttonwood mangrove (Conocarpus erectus) caused by hurricanes. Pruned plants grew faster than unpruned plants, produced lower levels of physical anti-herbivore defenses (trichomes, toughness), and higher levels of chemical defenses (tannins) and extrafloral nectaries. Thus, simulated hurricane damage increased plant growth and the amount of reward provided to ant mutualists, but did not have consistent effects on other anti-herbivore defenses. Both herbivores and ants increased in abundance on pruned plants, indicating that the effects of simulated hurricane damage on plant traits were propagated to higher trophic levels. Ant-exclusion led to higher leaf damage on both pruned and upruned plants. The effect of ant-exclusion did not differ between pruned and unpruned plants, despite the fact that pruned plants had higher ant and herbivore densities, produced more extrafloral nectaries, and had fewer physical defenses. Another common predator, clubionid spiders, increased in
\end{abstract}

Communicated by Phil Lester.

J. Piovia-Scott ( $\square)$

Center for Population Biology, University of California,

One Shields Avenue, Davis, CA 95616-8755, USA

e-mail: jpioviascott@ucdavis.edu abundance on pruned plants from which ants had been excluded. I suggest that compensatory predation by these spiders diminished the effect of ant-exclusion on pruned plants.

Keywords Compensatory predation $\cdot$ Conocarpus erectus $\cdot$ Extrafloral nectar · Herbivory $\cdot$ Trophic cascade

\section{Introduction}

Mutualisms are frequently facultative and context-dependent (Bronstein 1994, 1998). Physical disturbance has long been recognized as an important determinant of community and food-web dynamics (Menge and Sutherland 1976; Power et al. 1996; Spiller and Schoener 2007; Wootton et al. 1996), often changing the strength or direction of interspecific interactions. Variable outcomes are common in protective ant-plant mutualisms, in which plants provide rewards for ants and ants protect plants from herbivores (Bronstein 1998; Bronstein et al. 2006; Heil and McKey 2003; Rico-Gray and Oliveira 2007); however, few studies have explored the impact of physical disturbance on protective ant-plant mutualisms.

When woody plants re-sprout following disturbance, the new foliage frequently contains more nutrients and fewer anti-herbivore defenses than foliage on undisturbed plants (Radho-Toly et al. 2001; Spiller and Agrawal 2003; Vieira et al. 1996). Given these changes in edibility, it is not surprising that herbivores often have a greater impact on resprouted plants than undamaged plants (Bailey and Whitham 2002; Nakamura et al. 2005; Radho-Toly et al. 2001; Spiller and Agrawal 2003; Stein et al. 1992; Vieira et al. 1996). Enhanced edibility is also expected to facilitate stronger top-down effects of predators on plants, as changes 
in herbivore density or behavior resulting from predation should have stronger impacts on susceptible plants than on resistant plants (Leibold 1989; Polis and Strong 1996; Strong 1992; van der Stap et al. 2007).

Disturbance can also influence the top-down effects of predators by changing the composition of predator and herbivore communities (Menge and Sutherland 1987; Power et al. 1996; Wootton et al. 1996). For example, Spiller and Schoener (2007) found that hurricanes reduce the abundance of parasitoid wasps and web spiders and enhance the top-down effect of a lizard predator on plants. The authors suggest that the increased lizard effect is a result of the removal of arthropod predators-prior to the disturbance, arthropod predators may have been able to compensate for the lack of lizards. Thus, disturbance can influence the topdown effects of particular predators by altering the predator community.

Disturbance may also directly influence ant-plant mutualisms by affecting plant traits that are associated with ant activity. For example, leaf damage has been shown to increase the production of ant attractants in a number of different plants (Agrawal and Rutter 1998; Heil et al. 2001; Mondor and Addicott 2003; Ness 2003; Wackers et al. 2001). However, physical disturbance tends to remove shoots and branches, not just damage leaves, and plants respond differently to leaf damage and shoot removal (Haukioja et al. 1990). Like leaf damage, shoot removal can also lead to increased production of ant attractants (Huntzinger et al. 2004), but fewer studies have addressed this issue. Thus, there is some evidence that disturbance can increase the benefits provided to ant mutualists by their plant associates. If so, this may also enhance the protective effects of ants on disturbed plants.

This study examines the effect of simulated disturbance on mutualistic interactions between a mangrove and its ant associates. Conocarpus erectus (Combretaceae) inhabits tropical and subtropical shorelines around the world. Ants are attracted to extrafloral nectaries (EFNs) on the leaf blades and petioles; in turn, these ants can protect the plants from herbivores (Piovia-Scott 2010). Due to its shoreline habit, $C$. erectus is frequently exposed to disturbance caused by large storms. Hurricanes cause lower levels of some anti-herbivore defenses in C. erectus (Spiller and Agrawal 2003) and higher levels of herbivory (Spiller and Agrawal 2003; Spiller and Schoener 2007). Hurricanes also affect the predator community in $C$. erectus habitats. Wasp (Spiller and Schoener 2007) and spider (Spiller et al. 1998; Spiller and Schoener 2007) abundances are reduced by hurricanes, and lizard populations can be extirpated (Spiller et al. 1998), although this effect depends on the timing of the hurricane (Schoener et al. 2004). Ants, on the other hand, appear to be relatively resistant to hurricane disturbance (Morrison 2002).
A field experiment was used to investigate whether disturbance-induced changes in $C$. erectus traits affect the antplant mutualism. I manipulated ants and simulated hurricane damage in a factorial design, and measured plant growth, levels of anti-herbivore defense traits, leaf damage, herbivore abundance, and ant abundance for a year following the initiation of treatments. Specifically, I address the following questions: (1) Are plant growth and physical and chemical anti-herbivore defense traits affected by simulated hurricane damage? (2) Do damaged plants produce EFNs and recruit higher densities of mutualistic ants? (3) Does the effect of ant-exclusion differ on damaged and undamaged plants?

\section{Materials and methods}

Study system

This research was conducted on Staniel Cay $\left(24^{\circ} 10^{\prime} 11^{\prime \prime} \mathrm{N}\right.$, $76^{\circ} 26^{\prime} 24^{\prime \prime} \mathrm{W}$ ), an island in the Exuma chain in the central Bahamas. Conocarpus erectus is one of the most common shoreline plants in the Exumas. Extrafloral nectaries (EFNs) on C. erectus in this region are visited by a variety of insects, including ants, wasps, moths, beetles, and flies. The most common ant visitors are Camponotus tortuganus, Brachymyrmex obscurior, Crematogaster lucayana, Crematogaster steinheili, Dorymyrmex pyramicus, Pseudomyrmex pallidus and a Paratrechina sp. Honeydew-producing insects are very rare on $C$. erectus in the study area, so EFNs are the primary attractant for ant visitors (J. PioviaScott, personal observation). Antagonistic interactions between the dominant ant species (C. tortuganus) and the most common class of herbivores (chrysomelid beetles) have been observed (J. Piovia-Scott, personal observation), and ant-exclusion can increase herbivory and decrease growth rate in C. erectus (Piovia-Scott 2010).

Conocarpus erectus can live for several decades (Francis 2010), and the Bahamas have been hit by eight hurricanes in the past 20 years (Unisys 2010), suggesting that individual $C$. erectus recruiting into this region have a good chance of being affected by hurricanes. In shoreline areas exposed to the full force of hurricane winds and storm surges, almost all above-ground plant biomass is removed, leaving surviving individuals to re-sprout from their roots. In $C$. erectus, this re-sprouted foliage was found to have fewer trichomes, higher levels of herbivory, and to attract more adult moths than foliage on undamaged plants (Spiller and Agrawal 2003). In the Exumas, Conocarpus erectus generally occurs in two morphotypes- "silver" plants have a dense layer of trichomes on the leaf surface, while "green" plants have very few trichomes (Correll and Correll 1982; Semple 1970). Silver plants also have lower levels of herbivory than green plants, suggesting that 
trichomes are an effective defense against herbivory (Agrawal and Spiller 2004; Schoener 1987, 1988; Spiller and Schoener 1996). Pruning, which simulates hurricane disturbance (Spiller and Agrawal 2003), leads to reduced toughness, fewer trichomes, and higher leaf nitrogen in both morphotypes of $C$. erectus, but these effects are more pronounced for silver plants (Agrawal and Spiller 2004). In order to maximize the potential response to disturbance, I used only silver $C$. erectus plants in this study.

\section{Experimental design and data collection}

I used a $2 \times 2$ factorial randomized complete block design with the following four treatments: (1) unmanipulated controls_-ants and plants unaltered, (2) plants unaltered and ants excluded, (3) plants pruned and ants unaltered, and (4) plants pruned and ants excluded. The 40 silver $C$. erectus plants used in the experiment were divided into ten blocks of four plants based on spatial proximity; treatments were assigned randomly within each block. Plants in the pruning treatment were reduced to stumps, leaving enough of the trunk intact to install ant exclusions but removing all growing shoots. This treatment mimics the effects of the storm surges and wave action associated with hurricanes on C. erectus (Spiller and Agrawal 2003); it does not, however, simulate the effect of hurricanes on the arthropod community associated with $C$. erectus. Ants were excluded using Tree Tanglefoot ${ }^{\circledR}$ (The Tanglefoot Company) applied on top of a band of duct tape wrapped around the trunk of the plant; control plants had duct tape wrapped around their trunks but no tanglefoot applied on top of the tape. Tanglefoot barriers on $C$. erectus can effectively reduce ant abundances for at least 4 months under field conditions (Piovia-Scott 2010). Treatments were initiated in September 2007 and data were collected in December 2007, May 2008, and October 2008. Tanglefoot barriers were replaced at the end of each data collection period.

I collected leaves from experimental plants at the end of each sampling interval to measure anti-herbivore defense traits and leaf damage. To control for the effects of leaf age, I collected only leaves that had been produced since the previous sampling. This was accomplished by marking the most distal leaves present on four stems at the beginning of each interval, and only sampling those more apical than the marked leaves at the end of each interval (no leaves were marked on pruned plants at the beginning of the experiment, as all leaves were removed during pruning). A sample consisted of up to 20 new leaves produced by these four stems (the smallest sample was 10 leaves), representing anywhere from $0.01-10 \%$ of the total number of leaves on a plant. If the total number of leaves produced by these stems exceeded 20, I randomly selected 20 for data collection. I collected 20 leaves at random from each plant prior to the experiment to provide baseline data for plant traits. Also, I recorded whether or not the marked stems produced flowers during the final sampling period.

For each leaf sample, petiolar extrafloral nectaries were counted on each leaf. Trichome density was estimated by examining the surface of each leaf at $\times 50$ magnification and giving it a score from $0-3: 0=$ trichomes absent $\left(<1\right.$ per $\left.\mathrm{mm}^{2}\right)$, $1=$ trichomes sparse $\left(\sim 125\right.$ per $\left.\mathrm{mm}^{2}\right), 2=$ trichomes abundant $\left(\sim 250\right.$ per $\left.\mathrm{mm}^{2}\right), 3=$ trichomes completely covering leaf surface $\left(>375\right.$ per $\left.\mathrm{mm}^{2}\right)$. Toughness was measured on up to five randomly selected leaves from each sample using a force gauge penetrometer (Type 516; Chatillon). I calculated the mean EFN number, trichome index, and toughness per leaf for each sample for use in statistical analyses. Each sample of leaves was pressed and photographed for leaf damage analysis. Total leaf area and damaged area were measured from digital images using image-analysis software (SigmaScan; SPSS) and the percent of total leaf area damaged was estimated for each sample.

After being pressed and photographed, leaves were dried at ambient temperature using silica gel for use in tannin assays. Four leaves were selected at random from each sample and a 25-mg portion of each leaf was taken. These portions were combined to form a 100-mg sample for each plant. Samples were ground in plastic vials by adding liquid nitrogen and pulverizing leaf fragments with a plastic pestle. Tannins were extracted in $70 \%$ acetone for $60 \mathrm{~min}$ at room temperature, then centrifuged for $10 \mathrm{~min}$ at maximum speed; the supernatant was removed and its tannin concentration was assessed using the radial diffusion assay (Hagerman 1987). Briefly, a protein-containing agarose gel was poured into Petri dishes and allowed to solidify. Then, $15 \mu \mathrm{l}$ of leaf extract was placed in a well cut into the gel. After incubating at room temperature for $96 \mathrm{~h}$, a ring of precipitated protein was visible around wells containing tannins. Tannic acid standards were used to relate the area of the ring of precipitated protein to tannin content ( $\%$ dry weight).

There was very little growth in the unpruned plants between December 2007 and May 2008. Thus, in May 2008, I was unable to measure all the response variables on new leaves. I was able to collect growth and EFN data from new leaves, but there were not enough new leaves present on all plants to measure trichomes, tannins, toughness, and leaf damage. Instead, these measurements were taken from a sample of 20 randomly-selected leaves from each plant.

At the end of each sampling period, I measured arthropod density on experimental plants as follows. I examined all the foliage on each plant and counted the number of each taxonomic group seen on six separate occasions (three during daylight hours and three at night). Ants were identified to species, other groups were identified to family or order. I also counted the number of shoots on each plant, and calculated arthropod densities as number per shoot. 
Statistical analyses

Many plant defense traits were monitored in this experiment (trichomes, toughness, tannins, EFNs). In order to maintain an acceptable type I error rate, I conducted a MANOVA on plant defense traits; a significant MANOVA was followed by a series of univariate tests for individual response variables (Scheiner 2001). Other response variables (herbivory, growth, arthropod abundances) were analyzed using univariate tests.

Univariate analyses of most response variables were conducted with linear mixed models. Unlike other methods used in repeated measures ANOVA, mixed model analysis can handle datasets where some of the observations are missing from particular experimental units. Plant was a random factor and block, ant-exclusion, and pruning treatments were fixed factors. Sampling date was also a fixed effect, with each sampling date considered a repeated measure of each plant. Values of the response variables prior to the experiment were used as covariates; these were dropped from the model if they were not significant at $\alpha=0.05$. Non-significant interactions between fixed effects were dropped from the final models. I used a variance-component structure for random terms, which assumes that they are independent and additive. Arthropod densities were logtransformed to meet model assumptions. Treatment effects on the proportion of plants for which marked stems produced flowers during the final sampling period were analyzed using Fisher's exact test.

Some ant-exclusion plants had relatively high ant densities during certain sampling periods. The ant-exclusion treatment appeared to be ineffective for these plants, so these observations were removed from the analysis. The effectiveness of an ant-exclusion treatment was determined using outlier analysis based on the studentized deleted residual (Neter et al. 1996, pp. 373-375). If the ant density for an ant-exclusion plant was a positive outlier (at $\alpha=0.05$ ), the data from that plant during that sampling period were removed. This resulted in the removal of five observations from the data set (out of a total of 120).

All analyses were implemented in R (R Core Development Team 2005). Mixed model analyses were run using the lme function in the nlme package (Pinheiro et al. 2009).

\section{Results}

Effects of pruning on C. erectus and arthropods

Anti-herbivore defenses differed between pruned and unpruned plants (MANOVA: $F_{4,25}=35.7, p<0.0001$; Fig. 1a-d), with pruned plants possessing fewer physical defenses than unpruned plants, but higher levels of chemical and indirect defenses. Mean trichome density was reduced by $21 \%$ on pruned plants $\left(F_{1,28}=31.1, p<0.0001\right.$; Fig. 1a) and mean toughness was reduced by $27 \%$ $\left(F_{1,28}=60.5, p<0.0001\right.$; Fig. $\left.1 \mathrm{~b}\right)$; in both cases, the difference between pruned and unpruned plants diminished over the course of the experiment (pruning $\times$ date interaction: $F_{2,69}=16.6, p<0.0001, F_{2,69}=44.6, p<0.0001$, respectively). In contrast, pruned plants tended to have higher levels of chemical and indirect defenses than unpruned plants. Mean tannin concentration was $30 \%$ higher in pruned plants than in unpruned plants $\left(F_{1,28}=11.8, p=0.002\right.$; Fig. 1c) and pruned plants had $33 \%$ more EFNs than unpruned plants $\left(F_{1,28}=5.6, p=0.03\right.$; Fig. $\left.1 \mathrm{~d}\right)$. For tannins, the difference between pruned and unpruned plants decreased during the course of the experiment (date $\times$ pruning interaction: $F_{2,64}=9.9, \quad p=0.0002$; Fig. 1c), while EFNs did not show an effect of pruning until May 2008 (date $\times$ pruning interaction: $F_{2,58}=12.9$, $p<0.0001$; Fig. 1d).

The mean growth rate on pruned plants was twice the mean growth rate of unpruned plants $\left(F_{1,28}=34.7\right.$, $p<0.0001$; Fig. 1e), although the difference between pruned and unpruned plants decreased during the course of the experiment (pruning $\times$ date interaction: $F_{2,71}=14.1$, $p<0.0001)$. The difference in leaf damage between pruned and unpruned plants varied by date (pruning $x$ date interaction: $F_{2,69}=3.62, p=0.03$; Fig. 1f), tending to be higher in pruned plants in May $2008\left(F_{1,26}=3.09, p=0.09\right)$, but there was no overall effect of pruning on leaf damage $\left(F_{1,28}=0.13, p=0.72\right)$. Marked stems were more likely to produce flowers on unpruned plants (6 of 20 plants) than pruned plants ( 0 of 20 plants) during the final sampling period (Fisher's exact test: $p=0.02$ ).

Pruning increased arthropod densities. Mean herbivore density was eight times higher on pruned plants than on unpruned plants $\left(F_{1,28}=32.9, p<0.0001\right.$; Fig $\left.2 a\right)$, and mean ant density was 29 times higher on pruned plants on average $\left(F_{1,28}=23.5, p<0.0001\right.$; Fig $\left.2 b\right)$. The difference in ant densities was particularly pronounced in December 2007 (pruning $\times$ date interaction: $F_{2,71}=12.7, p<0.0001$ ). The mean number of herbivores counted on pruned plants was greater than the mean number on unpruned plants $(3.80$ vs 1.76 , respectively) - the same was true for ants (5.88 vs 2.29 , respectively)—indicating that the increase in herbivore and ant densities (individuals per shoot) on pruned plants was not a statistical artifact associated with the reduction in shoot numbers caused by the pruning treatment. Ants were the most common predator observed, representing $78 \%$ of all arthropod predator observations. Camponotus tortuganus was the most abundant ant species on both pruned and unpruned plants during all sampling periods, representing $75 \%$ of all ants observed. After ants, 
Fig. 1 The effect of factorial manipulations of pruning and ant-exclusion on Conocarpus erectus: a trichomes

b toughness c tannins d EFNs per leaf e growth and $\mathbf{f}$ leaf damage ( $n=10$ plants for each treatment combination). The vertical dotted line represents the initiation of treatments. Means and standard errors are shown, with the predicted mean of post-treatment samples for each plant presented at the right of each plot. Predictions were obtained from the mixed models described in the text. Statistical significance of tests comparing pruned and unpruned plants are shown: $* * * p<0.001, * * p<0.01$, ${ }^{*} p<0.05,{ }^{+} p<0.1$

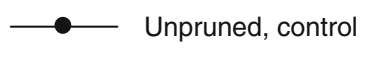

$-\rightarrow-$ Unpruned, exclusion
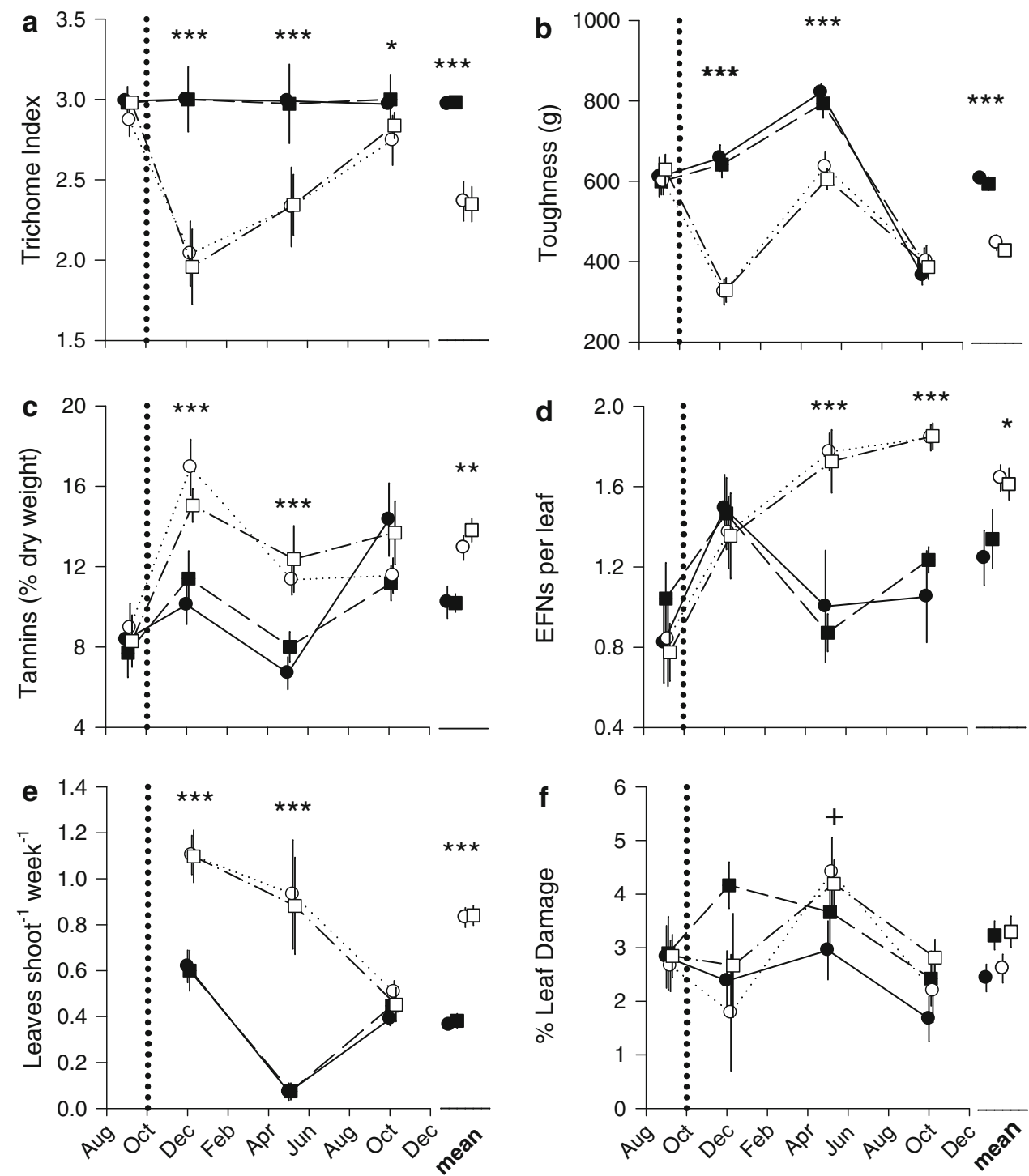

.......... Pruned, control

$-\neg \square \cdot-$ Pruned, exclusion
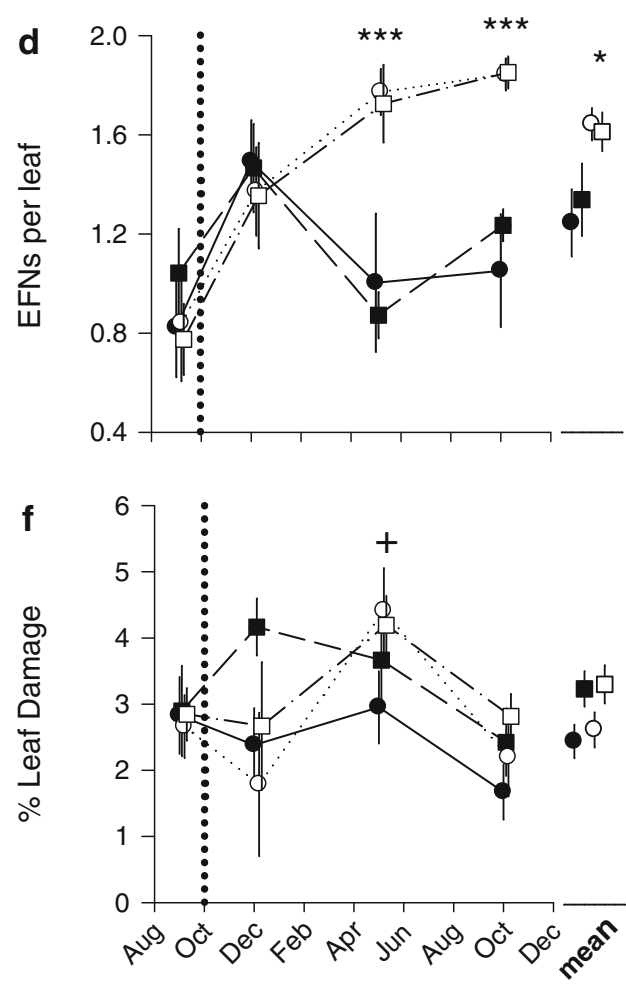

clubionid spiders (Elaver sp.) were among the most common predators observed on $C$. erectus in this experiment. These spiders are active, nocturnal hunters and were observed consuming the folivorous chrysomelid beetles that were the most common herbivore observed in this study. Overall, there was a marginally significant tendency for higher clubionid densities on pruned plants $\left(F_{1,28}=4.0\right.$, $p=0.05$; Fig. 2c). However, in May, when clubionid spiders were most abundant, their density on pruned, ant-exclusion plants was an order of magnitude higher than on any of the other treatment groups (pruning $\times$ ant treatment $\times$ date interaction: $F_{2,67}=4.5, p=0.01$; pruning $x$ ant interaction in May 2008: $F_{1,24}=5.8$, $p=0.02$; Fig. 2c).
Effects of ant-exclusion on C. erectus and arthropods

Leaf damage was $27 \%$ higher on ant-exclusion plants than on control plants $\left(F_{1,28}=5.0, p=0.03\right.$; Fig. 1f $)$. There was no indication, however, that this effect differed for pruned and unpruned plants (ant-exclusion $\times$ pruning interaction: $\left.F_{1,27}=0.86, p=0.36\right)$. Growth did not differ between ant-exclusion and control plants $\left(F_{1,28}=0.002, p=0.96\right.$; Fig. 1e), and there was no detectable influence of the ant-exclusion treatment on trichomes, toughness, tannins, and EFNs (MANOVA: $F_{4,25}=0.36, p=0.83$; Fig. $1 \mathrm{a}-\mathrm{d}$ ). Marked stems produced flowers on the same number of antexclusion and control plants ( 3 of 20 in both cases) during the final sampling period. 

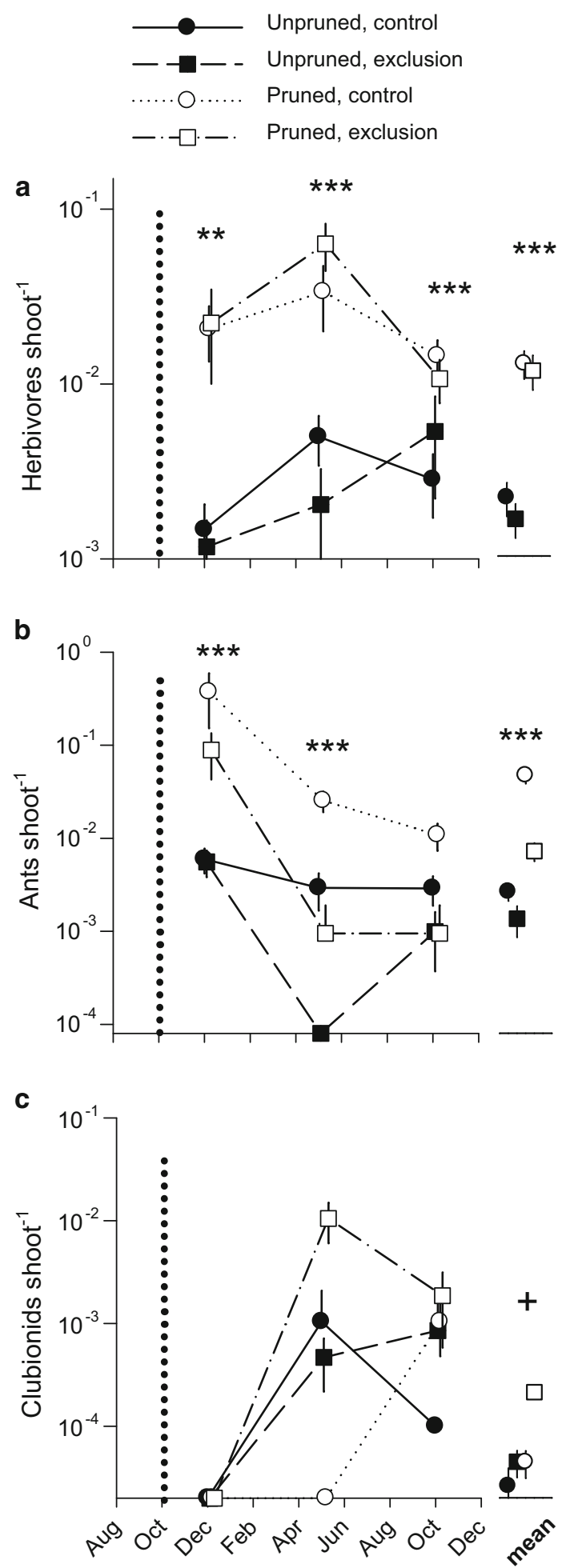

Fig. 2 The effect of factorial manipulations of pruning and ant-exclusion on arthropod densities: a herbivores $\mathbf{b}$ ants and $\mathbf{c}$ clubionid spiders ( $n=10$ plants for each treatment combination). The vertical dotted line represents the initiation of treatments. Means and standard errors are shown, with the predicted means for post-treatment samples of each plant presented at the right of each plot. Insect densities are plotted on a log scale. Statistical significance of tests comparing pruned and unpruned plants are shown: $* * * p<0.001, * * p<0.01$, ${ }^{*} p<0.05 .{ }^{+} p<0.1$
Analyses of the effect of ant-exclusion on ant densities confirmed that the ant-exclusion treatment was effective (ant-exclusion effect: $F_{1,28}=21.8, p=0.0001$; Fig. 2b). However, the difference in ant density between ant-exclusion and control plants was greater for pruned plants than for unpruned plants (pruning $\times$ ant-exclusion interaction: $F_{1,27}=$ 10.2, $p=0.004$; Fig. 2b). Analyses of the simple effects confirmed that the ant-exclusion treatment effectively reduced ant densities in both pruned plants (70\% reduction; $\left.F_{1,9}=18.2, p=0.002\right)$ and unpruned plants (34\% reduction; $\left.F_{1,9}=6.7, p=0.03\right)$. Overall, ant-exclusion led to a fivefold increase in clubionid spider density $\left(F_{1,28}=4.9\right.$, $p=0.03$; Fig. 2c). As mentioned above, clubionid spiders were more abundant on pruned, ant-exclusion plants in May 2008. Ant-exclusion did not affect herbivore density $\left(F_{1,28}=0.40, p=0.53\right.$; Fig. 2a $)$.

\section{Discussion \\ Bottom-up effects of simulated disturbance}

There were strong effects of simulated disturbance on plant traits, with pruned plants displaying increased growth, decreased trichome density and toughness, and increased levels of tannins and EFNs. These changes in plant characteristics were associated with higher herbivore and ant densities on pruned plants. Previous studies of $C$. erectus in this system demonstrated that simulated hurricane damage decreases trichome density and toughness (Agrawal and Spiller 2004; Spiller and Agrawal 2003), and increases the abundance of herbivores and parasitoid wasps (Spiller and Agrawal 2003). However, these studies did not consider the effect of damage on the interaction between $C$. erectus and its ant mutualists, nor did they measure growth or chemical defenses, such as tannins, on pruned and unpruned plants.

It has been proposed that the breakdown of apical dominance resulting from pruning or browsing by mammals leads to an increase in the amount of vigorously growing foliage that is rich in nutrients but poor in defenses (Honkanen and Haukioja 1998). The predicted increase in edibility in response to branch removal has been observed in many studies (Agrawal and Spiller 2004; Bryant 2003; Danell et al. 1997; Danell and Huss-Danell 1985; Nakamura et al. 2006; Nykanen and Koricheva 2004; Spiller and Agrawal 2003; Valkama et al. 2005). However, branch removal by hurricane disturbance can lead to increased chemical defense (Hunter and Forkner 1999), and browsing by mammals has been shown to increase both chemical defense (Martinsen et al. 1998) and the production of ant attractants (Huntzinger et al. 2004). The results of the current experiment are consistent with those of previous studies-pruning elicited faster growth, reduced physical defenses, and enhanced 
the production of chemical defenses and EFNs in C. erectus. Different traits, however, did not follow the same trajectory after the manipulation. Pruning led to dramatic changes in growth, trichomes, toughness, and tannins within 3 months of the manipulation, but these differences diminished for the remainder of the year-long experiment (Fig 1a-c, e). In contrast, differences in EFN production did not appear until 9 months after the manipulation, but these differences were sustained throughout the remainder of the experiment. This delayed response in EFN production may be a result of physiological constraints on EFN production.

It is clear that $C$. erectus responds to pruning by changing its pattern of allocation to different functions. In the months following pruning, $C$. erectus grows rapidly (Fig. 1e) and increases the nitrogen content of its foliage (Agrawal and Spiller 2004; Spiller and Agrawal 2003). As a consequence, scarce supplies of nitrogen and other resources are probably devoted largely to growth at the expense of other functions, such as physical defense and reproduction (Herms and Mattson 1992). In addition, leaves on fast-growing, pruned $C$. erectus might have shorter lifetimes than those on unpruned plants, potentially reducing the value of investments in anti-herbivore defense (Coley et al. 1985). These hypotheses may help explain why trichomes and toughness were reduced in pruned plants, and why pruned plants did not appear to produce as many flowers as unpruned plants, but do not explain the increase in tannins and EFNs. The synthesis of some types of tannins is biochemically decoupled from protein synthesis and plant growth, which may account for the lack of a tradeoff between growth and tannin concentration (Haukioja et al. 1998). In addition, previous studies have documented a trade-off between trichomes and EFNs in undisturbed C. erectus. Plants with low trichome density (the "green" morphotype) have more EFNs than plants with high trichome density (the "silver" morphotype) (Piovia-Scott 2010); they also have higher levels of herbivory (Agrawal and Spiller 2004; Schoener 1988; Spiller and Schoener 1996), are more affected by ant attendants, and tend to grow faster (Piovia-Scott 2010). Interestingly, the changes in anti-herbivore defenses observed following pruning are consistent with a switch between existing defense syndromes in C. erectus.

The increase in herbivore density on pruned plants suggests that toughness and trichomes were more effective deterrents against herbivores than tannins and ants, or that the increase in the nutritional quality of the rapidly-growing foliage made pruned plants more attractive, despite their defenses. These hypotheses are consistent with the observation that the difference in herbivore density between pruned and unpruned plants was diminished in the last sampling period (Fig. 2a), when toughness, trichomes, and growth were similar in pruned and unpruned plants (Fig. 1a, b, e).
The nutritional quality of the foliage may have been especially important in May, when there was much more actively-growing foliage available on pruned plants than on unpruned plants (Fig. 1f), and leaf damage on pruned plants tended to be higher than on unpruned plants (Fig. 1e). Increased nectar production may also have contributed to higher herbivore densities on pruned plants, as herbivores have been seen visiting EFNs (J. Piovia-Scott, personal observation).

The effects of branch removal can be propagated up to the third trophic level, as increased abundances of herbivores can attract more predaceous arthropods (Nakamura et al. 2005, 2006; Schoener 1988; Spiller and Agrawal 2003). For $C$. erectus, increased EFN production may also contribute to higher ant densities, as $C$. erectus plants with more EFNs attract more ants (Piovia-Scott 2010). For the first 3 months of the experiment, increased herbivore density likely explains higher ant abundances on pruned C. erectus, as EFNs had not yet responded to the treatment. During the remainder of the experiment, increased production of extrafloral nectar likely contributed to higher ant densities.

Top-down effects of simulated disturbance

Ant exclusion led to lower levels of herbivory, indicating that ants were effective mutualists during the course of the experiment. However, the effect of ant-exclusion did not differ between pruned and unpruned plants. This result is somewhat surprising, as pruned plants were expected to receive more of a benefit from ants due to their low levels of physical defense traits and high EFN density (Piovia-Scott 2010). Furthermore, pruned plants had higher herbivore densities and a greater difference in ant densities between ant-exclusion and control plants, both of which are also expected to increase the difference in herbivory between ant-exclusion and control plants (Barton 1986; Di Giusto et al. 2001; Rudgers and Strauss 2004).

There are a number of potential explanations for the absence of a stronger effect of ants on pruned plants. For example, if tannins and ant associates are redundant, increased levels of tannins in pruned plants could diminish the effect of ants. However, the absence of a relationship between tannin concentration and leaf damage $(p>0.47$ in all plausible models) suggests that this is not the case. Alternatively, the benefits provided by ants to plants may saturate at high ant densities (Ness et al. 2006). If this is the case, the greater difference in ant density between control and ant-exclusion treatments for pruned plants may not lead to a larger beneficial effect of ants. However, pruned plants also had higher herbivore densities, which may maintain the per-capita effects of ants at a relatively high level as ant densities increase. 
A third explanation is that pruned plants attract more alternate predators, which can compensate for the lack of ants. This seems to be the case-on pruned plants, the exclusion of ants allowed alternate predators (in this case, clubionid spiders) to increase in density. Antagonistic interactions between ants and clubionid spiders have been observed, suggesting that these spiders avoid plants where ants are abundant. Clubionids are probably able to circumvent the tanglefoot barriers by ballooning, allowing them to colonize ant-exclusion plants, and they are likely attracted to the abundant prey on vigorously growing pruned plants. High clubionid density on pruned, ant-exclusion plants could limit herbivory, diminishing the top-down effects of ants. Ant-exclusion has led to increases in spider density in a number of other systems (Halaj et al. 1997; Izzo and Vasconcelos 2005; Mody and Linsenmair 2004; Mooney 2007), suggesting that these two predator guilds may frequently have compensatory effects on lower trophic levels.

The effect of hurricanes on island food webs in the Bahamas

The pruning treatment employed in this study was designed to simulate the effect of hurricane storm surges on C. erectus. Unfortunately, this treatment does not simulate the direct effects of hurricanes on arthropods, complicating the inferences one can draw from this study concerning the influence of hurricane disturbance on ant $-C$. erectus interactions. In previous studies conducted on small Bahamian islands, herbivores recover relatively quickly following hurricanes (Spiller and Agrawal 2003), and some ant species appear to be resistant to hurricane disturbance (Morrison 2002). In contrast, other arthropod predators, including spiders, recover relatively slowly following disturbance (Spiller et al. 1998; Spiller and Schoener 2007).

Since both herbivores and ants appear to persist or rapidly recolonize areas disturbed by hurricanes, some of the effects observed in this study may provide a reasonable representation of what happens in communities affected by hurricanes. Herbivores are likely to be attracted to the high quality foliage, and ants likely recruit to plants in higher numbers due to increased herbivore abundance and extrafloral nectar production. On the other hand, the top-down effects observed in this study may not provide an adequate representation of dynamics in communities affected by hurricanes, as the lack of alternate arthropod predators may prevent compensatory predation from occurring. Indeed, the lack of compensatory predation by parasitoid wasps, web spiders, and other predatory arthropods is likely responsible for the magnified effect of lizards on leaf damage following hurricanes (Spiller and Schoener 2007). Thus, it is possible that the effects of ants following a hurricane could be enhanced in the absence of compensatory predation by other arthropods.

\section{Conclusion}

This study outlines clear bottom-up effects of simulated hurricane disturbance and top-down effects of ant mutualists, but does not find evidence for an interaction between the two. The bottom-up effects of simulated disturbance were propagated up to the predator trophic level, with ants likely responding both to increases in nectar production by the plants and increases in herbivore abundance. Although pruned plants were more attractive to herbivores, there was not a universal decrease in anti-herbivore defense traits in response to pruning. Instead, there was a shift in patterns of allocation in favor of different types of defense in pruned plants. In contrast to previous studies, there was no indication that disturbance facilitated topdown control by ants, probably because alternative predators were able to compensate for the loss of ants on pruned plants.

Acknowledgments This research was made possible by funding from the University of California-Davis Center for Population Biology to J.P.S., with additional support provided by National Science Foundation grants DEB-0808323 to J.P.S and Thomas W. Schoener, DEB0516431 to David A. Spiller and Thomas W. Schoener. D.A. Spiller, L.H. Yang, and A.N. Wright provided indispensable advice and assistance in the field and R. Chia helped analyze leaf damage. The manuscript was greatly improved by comments from D.A. Spiller, T.W. Schoener, M.L. Stanton, A.N. Wright, and L.H. Yang. P.S. Ward helped identify ants.

Open Access This article is distributed under the terms of the Creative Commons Attribution Noncommercial License which permits any noncommercial use, distribution, and reproduction in any medium, provided the original author(s) and source are credited.

\section{References}

Agrawal AA, Rutter MT (1998) Dynamic anti-herbivore defense in ant-plants: the role of induced responses. Oikos 83:227-236

Agrawal AA, Spiller DA (2004) Polymorphic buttonwood: effects of disturbance on resistance to herbivores in green and silver morphs of a Bahamian shrub. Am J Bot 91:1990-1997

Bailey JK, Whitham TG (2002) Interactions among fire, aspen, and elk affect insect diversity: reversal of a community response. Ecology 83:1701-1712

Barton AM (1986) Spatial variation in the effect of ants on an extrafloral nectary plant. Ecology 67:495-504

Bronstein JL (1994) Conditional outcomes in mutualistic interactions. Trends Ecol Evol 9:214-217

Bronstein JL (1998) The contribution of ant plant protection studies to our understanding of mutualism. Biotropica 30:150-161

Bronstein JL, Alarcon R, Geber M (2006) The evolution of plant-insect mutualisms. New Phytol 172:412-428

Bryant JP (2003) Winter browsing on Alaska feltleaf willow twigs improves leaf nutritional value for snowshoe hares in summer. Oikos 102:25-32

Coley PD, Bryant JP, Chapin FS (1985) Resource availability and plant antiherbivore defense. Science 230:895-899

Correll DS, Correll HB (1982) Flora of the Bahama Archipelago. Cramer, Vaduz, Liechtenstein 
Danell K, Huss-Danell K (1985) Feeding by insects and hares on birches earlier affected by moose browsing. Oikos 44:75-81

Danell K, Haukioja E, Huss-Danell K (1997) Morphological and chemical responses of mountain birch leaves and shoots to winter browsing along a gradient of plant productivity. Ecoscience 4:296-303

Di Giusto B, Anstett MC, Dounias E, McKey DB (2001) Variation in the effectiveness of biotic defence: the case of an opportunistic ant-plant protection mutualism. Oecologia 129:367-375

Francis JK (2010) Conocarpus erectus L. In: Francis JK (ed) Wildland Shrubs of the United States and its Territories: Thamnic Descriptions. Accessed 12 Aug 2010. United States Department of Agriculture, Forest Service, http://www.fs.fed.us/global/iitf/pdf/ shrubs/Conocarpus\%20erectus.pdf

Hagerman AE (1987) Radial diffusion method for determining tannin in plant extracts. J Chem Ecol 13:437-449

Halaj J, Ross DW, Moldenke AR (1997) Negative effects of ant foraging on spiders in Douglas-fir canopies. Oecologia 109:313-322

Haukioja E, Ruohomaki K, Senn J, Suomela J, Walls M (1990) Consequences of herbivory in the mountain birch (Betula pubescens ssp tortuosa): importance of the functional organization of the tree. Oecologia 82:238-247

Haukioja E, Ossipov V, Koricheva J, Honkanen T, Larsson S, Lempa K (1998) Biosynthetic origin of carbon-based secondary compounds: cause of variable responses of woody plants to fertilization? Chemoecology 8:133-139

Heil M, McKey D (2003) Protective ant-plant interactions as model systems in ecological and evolutionary research. Annu Rev Ecol Evol Syst 34:425-453

Heil M, Koch T, Hilpert A, Fiala B, Boland W, Linsenmair KE (2001) Extrafloral nectar production of the ant-associated plant, $\mathrm{Mac}$ aranga tanarius, is an induced, indirect, defensive response elicited by jasmonic acid. Proc Natl Acad Sci USA 98:1083-1088

Herms DA, Mattson WJ (1992) The dilemma of plants: to grow or defend. Q Rev Biol 67:283-335

Honkanen T, Haukioja E (1998) Intra-plant regulation of growth and plant-herbivore interactions. Ecoscience 5:470-479

Hunter MD, Forkner RE (1999) Hurricane damage influences foliar polyphenolics and subsequent herbivory on surviving trees. Ecology 80:2676-2682

Huntzinger M, Karban R, Young TP, Palmer TM (2004) Relaxation of induced indirect defenses of acacias following exclusion of mammalian herbivores. Ecology 85:609-614

Izzo TJ, Vasconcelos HL (2005) Ants and plant size shape the structure of the arthropod community of Hirtella myrmecophila, an Amazonian ant-plant. Ecol Entomol 30:650-656

Leibold MA (1989) Resource edibility and the effects of predators and productivity on the outcome of trophic interactions. Am Nat 134:922-949

Martinsen GD, Driebe EM, Whitham TG (1998) Indirect interactions mediated by changing plant chemistry: beaver browsing benefits beetles. Ecology 79:192-200

Menge BA, Sutherland JP (1976) Species diversity gradients: synthesis of the roles of predation competition and temporal heterogeneity. Am Nat 110:351-369

Menge BA, Sutherland JP (1987) Community regulation: variation in disturbance, competition, and predation in relation to environmental stress and recruitment. Am Nat 130:730-757

Mody K, Linsenmair KE (2004) Plant-attracted ants affect arthropod community structure but not necessarily herbivory. Ecol Entomol 29:217-225

Mondor EB, Addicott JF (2003) Conspicuous extra-floral nectaries are inducible in Vicia faba. Ecol Lett 6:495-497

Mooney KA (2007) Tritrophic effects of birds and ants on a canopy food web, tree growth, and phytochemistry. Ecology 88:2005-2014
Morrison LW (2002) Island biogeography and metapopulation dynamics of Bahamian ants. J Biogeogr 29:387-394

Nakamura M, Utsumi S, Miki T, Ohgushi T (2005) Flood initiates bottom-up cascades in a tri-trophic system: host plant regrowth increases densities of a leaf beetle and its predators. J Anim Ecol 74:683-691

Nakamura M, Kagata H, Ohgushi T (2006) Trunk cutting initiates bottom-up cascades in a tri-trophic system: sprouting increases biodiversity of herbivorous and predaceous arthropods on willows. Oikos 113:259-268

Ness JH (2003) Catalpa bignonioides alters extrafloral nectar production after herbivory and attracts ant bodyguards. Oecologia 134:210-218

Ness JH, Morris WF, Bronstein JL (2006) Integrating quality and quantity of mutualistic service to contrast ant species protecting Ferocactus wislizeni. Ecology 87:912-921

Neter J, Kutner MH, Nachstheim CJ, Wasserman W (1996) Applied linear statistical models, 4th edn. Mcgraw-Hill, Boston

Nykanen H, Koricheva J (2004) Damage-induced changes in woody plants and their effects on insect herbivore performance: a metaanalysis. Oikos 104:247-268

Pinheiro J, Bates D, DebRoy S, Sarkar D, and the R Core team (2009) nlme: linear and nonlinear mixed effects models. $\mathrm{R}$ package version 3.1-96

Piovia-Scott J (2010) Plant phenotype influences the effect of ant mutualists on a polymorphic mangrove. J Ecol (in press)

Polis GA, Strong DR (1996) Food web complexity and community dynamics. Am Nat 147:813-846

Power ME, Parker MS, Wootton JT (1996) Disturbance and food chain length in rivers. In: Polis GA, Winemiller KO (eds) Food webs: integration of patterns and dynamics. Chapman \& Hall, London, pp 286-297

R Development Core Team (2005) R: a language and environment for statistical computing. R Foundation for Statistical Computing, Vienna, Austria

Radho-Toly S, Majer JD, Yates C (2001) Impact of fire on leaf nutrients, arthropod fauna and herbivory of native and exotic eucalypts in Kings Park, Perth, Western Australia. Austral Ecol 26:500-506

Rico-Gray V, Oliveira PS (2007) The ecology and evolution of antplant interactions. University of Chicago Press, Chicago

Rudgers JA, Strauss SY (2004) A selection mosaic in the facultative mutualism between ants and wild cotton. Proc R Soc Lond B 271:2481-2488

Scheiner SM (2001) MANOVA: multiple response variables and multispecies interactions. In: Scheiner SM, Gurevitch J (eds) Design and analysis of ecological experiments. Oxford University Press, New York, pp 99-115

Schoener TW (1987) Leaf pubescence in buttonwood: community variation in a putative defense against defoliation. Proc Natl Acad Sci USA 84:7992-7995

Schoener TW (1988) Leaf damage in island buttonwood, Conocarpus erectus: correlations with pubescence, island area, isolation and the distribution of major carnivores. Oikos 53:253-266

Schoener TW, Spiller DA, Losos JB (2004) Variable ecological effects of hurricanes: the importance of seasonal timing for survival of lizards on Bahamian islands. Proc Natl Acad Sci USA 101:177-181

Semple JC (1970) The distribution of pubescent leaved individuals of Conocarpus erectus: Combretaceae. Rhodora 72:544-547

Spiller DA, Agrawal AA (2003) Intense disturbance enhances plant susceptibility to herbivory: natural and experimental evidence. Ecology 84:890-897

Spiller DA, Schoener TW (1996) Food-web dynamics on some small subtropical islands: effects of top and intermediate predators. In: Polis GA, Winemiller KO (eds) Food webs: integration of patterns and dynamics. Chapman \& Hall, New York, pp 160-169 
Spiller DA, Schoener TW (2007) Alteration of island food-web dynamics following major disturbance by hurricanes. Ecology 88:37-41

Spiller DA, Losos JB, Schoener TW (1998) Impact of a catastrophic hurricane on island populations. Science 281:695-697

Stein SJ, Price PW, Abrahamson WG, Sacchi CF (1992) The effect of fire on stimulating willow regrowth and subsequent attack by grasshoppers and elk. Oikos 65:190-196

Strong DR (1992) Are trophic cascades all wet? Differentiation and donor control in speciose ecosystems. Ecology 73:747-754

Unisys (2010) Atlantic Tropical Storm Tracking by Year. http:// weather.unisys.com/hurricane/atlantic/index.html. Accessed 12 Aug 2010

Valkama E, Koricheva J, Ossipov V, Ossipova S, Haukioja E, Pihlaja K (2005) Delayed induced responses of birch glandular trichomes and leaf surface lipophilic compounds to mechanical defoliation and simulated winter browsing. Oecologia 146:385-393

van der Stap I, Vos M, Verschoor AM, Helmsing NR, Mooij WM (2007) Induced defenses in herbivores and plants differentially modulate a trophic cascade. Ecology 88:2474-2481

Vieira EM, Andrade I, Price PW (1996) Fire effects on a Palicourea rigida (Rubiaceae) gall midge: a test of the plant vigor hypothesis. Biotropica 28:210-217

Wackers FL, Zuber D, Wunderlin R, Keller F (2001) The effect of herbivory on temporal and spatial dynamics of foliar nectar production in cotton and castor. Ann Bot 87:365-370

Wootton JT, Parker MS, Power ME (1996) Effects of disturbance on river food webs. Science 273:1558-1561 